\title{
Influence of Titanium Oxide on Creep Behavior, Microstructure and Physical Properties of Tin-Antimony and Tin-Aluminum-Antimony Based Bearing Alloys
}

\author{
Abu Bakr El- Bediwi \\ Metal Physics Lab., Physics \\ Department, Faculty of Science, \\ Mansoura University \\ Mansoura, Egypt
}

\author{
Maison Hamid Grayb \\ Ministry of education \\ Iraq
}

\author{
Mustafa Kamal \\ Metal Physics Lab., Physics \\ Department, Faculty of Science, \\ Mansoura University \\ Mansoura, Egypt
}

\begin{abstract}
Influence of adding titanium oxide $\left(\mathrm{TiO}_{2}\right)$ nanoparticles on creep behavior, structure, mechanical and thermal properties of tinantimony-lead and tin-aluminum-antimony bearing alloys have been studied and analyzed. Stress exponent of tin- antimony- lead and tinaluminum- antimony- lead alloys decreased after adding titanium oxide. Elastic modulus of tin- antimony- lead increased after adding titanium oxide. Internal fiction of tin- antimony- lead and tin- aluminum- antimony- lead alloys varied after adding titanium oxide. Microstructure of tinantimony- lead and tin- aluminum- antimony- lead alloys changed after adding titanium oxide. Strengths of tin- antimony- lead and tin- aluminumantimony- lead alloys increased after adding titanium oxide. Thermal parameters of tin- antimony- lead and tin- aluminum- antimony- lead alloys varied after adding titanium oxide. The $\mathrm{Sn}_{79} \mathrm{Sb}_{15} \mathrm{~Pb}_{5}\left(\mathrm{TiO}_{2}\right)_{1}$ alloy has better bearing properties such as lowest internal friction, high elastic modulus and higher thermal diffusivity for industrial applications
\end{abstract}

Key words: stress exponent, titanium oxide, bearing alloys, internal fiction, creep indentation, thermal properties, mechanical properties

\section{INTRODUCTION}

Bearing is a device to allow constrained relative motion between two or more parts, typically rotation or linear movement. Bearing is a device used to transmit loads between relatively moving surfaces. The tribological properties of tin-based bearing alloys with different compositions, (7\% and 20\%), have been investigated [1]. Structure, electrical resistivity and elastic modulus of $\mathrm{SnSb}_{7} \mathrm{X}(\mathrm{X}=0$, $\mathrm{Cu}, \mathrm{Ag}$, or $\mathrm{Cu}$ and $\mathrm{Ag}$ ) and $\mathrm{Pb}_{63-\mathrm{x}} \mathrm{Sn}_{30} \mathrm{Sb}_{7} \mathrm{Cu}_{\mathrm{x}}[\mathrm{x}=0$ or $\mathrm{x} \leq 2.5]$ alloys have been studied and analyzed $[2,3]$. Electrical resistivity, elastic modulus and internal friction of $\mathrm{Pb}_{63} \mathrm{Sn}_{30} \mathrm{Sb}_{7}$ decreases after adding $\mathrm{Cu}$. Mechanical properties of $\mathrm{Sn}-\mathrm{Sb}$ bearing alloy have been evaluated [4]. Mechanical properties of Sn-Sb improved after adding $1 \mathrm{wt} . \%$ of $\mathrm{Cu}$ or Ag. Also the elastic modulus, internal friction and stiffness of $\mathrm{Sn}-\mathrm{Sb}$ based bearing alloys varied after annealing for 2 and $4 \mathrm{~h}$ at 120 , 140 and $160^{\circ} \mathrm{C}$. Creep behavior of $\mathrm{SnSb}_{5}$ alloy and

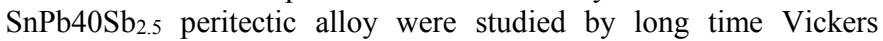
indentation testing at room temperature [5- 7]. Increasing Sb content from $7.5 \%$ to $20 \%$ provided an increase in hardness. Tensile properties of $\mathrm{SnSb}_{5} \mathrm{Bi}_{1.5}$ and $\mathrm{SnSb}_{5} \mathrm{Cu}_{1.5}$ alloys have been studied at different strain rates ranging from $5 \times 10^{-4}$ to $1 \times 10^{-2} \mathrm{~s}^{-1}$ over the wide temperature range of 298-400 K [8]. Strength and ductility of $\mathrm{SnSb}_{5}$ improved after adding $\mathrm{Bi}$ and $\mathrm{Cu}$. Creep behavior, elastic modulus and internal friction of $\mathrm{SnSb}_{10} \mathrm{Cu}_{2} \mathrm{X}_{2}(\mathrm{X}=\mathrm{Pb}, \mathrm{Ag}, \mathrm{Se}, \mathrm{Cd}$ and $\mathrm{Zn})$ alloys have been investigated and stress exponents have been determined [9]. The effect of solidification rate, heating and micro additions on microstructure and hardness of tin-based white metals have been studied $[10,11]$. Rapid cooling suppresses formation and growth of SbSn cuboids and increases hardness. Structure, hardness, mechanical and electrical transport properties of $\mathrm{Sn}_{90-\mathrm{x}} \mathrm{Sb}_{10} \mathrm{Bi}_{\mathrm{x}}(\mathrm{x}=0$, or $\mathrm{x} \geq 1)$ alloys have been studied and analyzed [12]. Electrical resistivity and hardness of $\mathrm{SnSb}_{10}$ increased after adding bismuth content. Internal friction, elastic modulus and thermal diffusivity of $\mathrm{SnSb}_{10}$ decreased after adding bismuth content. The effects of small amounts of Ag and $\mathrm{Cu}$ on the as-cast microstructure and creep properties of the $\mathrm{SnSb}_{5}$ alloy have been investigated [13]. Small additions of $\mathrm{Ag}$ and $\mathrm{Cu}$ elements could effectively change the creep behavior of the $\mathrm{SnSb}_{5}$ alloy. The friction coefficients of

$\mathrm{SnSb}_{20.2} \mathrm{~Pb}_{16.6} \mathrm{Cu}_{2.6}$ is lower than that of $\mathrm{SnSb}_{7.2} \mathrm{~Pb}_{0.4} \mathrm{Cu}_{3}$ under all scratch test conditions [14]. The directionally solidified microstructure of $\mathrm{SnSb}_{16}$ hyperperitectic alloy has been investigated at various solidification rates using a high-thermal gradient directional solidification apparatus [15]. The volume fraction of the $\mathrm{SnSb}$ phase firstly decreased and then increased when the solidification rate increased. The aim of this work was to study and analyze the effects of adding titanium oxide nanoparticles on creep behavior, structure, mechanical and thermal properties of tin-antimony-lead and tinaluminum-antimony based alloys.

\section{EXPERIMENTAL WORK}

Two groups of alloys, $\mathrm{Sn}_{80-\mathrm{x}} \mathrm{Sb}_{15} \mathrm{~Pb}_{5}\left(\mathrm{TiO}_{2}\right)_{\mathrm{x}}(\mathrm{x}=0.5,1$ and 1.5 wt.\%) and $\mathrm{Sn}_{60-x} \mathrm{Al}_{20} \mathrm{Sb}_{15} \mathrm{~Pb}_{5}\left(\mathrm{TiO}_{2}\right)_{\mathrm{x}}(\mathrm{x}=0.5,1$ and 1.5 wt.\%), were molten in the muffle furnace. Using elements tin, antimony, lead, aluminum and titanium oxide have a high purity, more than $99.95 \%$. The resulting ingots were turned and re-melted several times to increase the homogeneity of the ingots. From these ingots, long ribbons of about 3-5 mm width and $\sim 70 \mu \mathrm{m}$ thickness were prepared as the test samples by directing a stream of molten alloy onto the outer surface of rapidly revolving copper roller with surface velocity $31 \mathrm{~m} / \mathrm{s}$ giving a cooling rate of $3.7 \times 10^{5} \mathrm{k} / \mathrm{s}$. The samples then cut into convenient shape for the measurements using double knife cuter. Structure of used alloys was performed using an Shimadzu $\mathrm{x}$-ray diffractometer (Dx-30, Japan) of $\mathrm{Cu}-\mathrm{K} \alpha$ radiation with $\lambda=1.54056 \AA$ at $45 \mathrm{kV}$ and $35 \mathrm{~mA}$ and $\mathrm{Ni}-$ filter in the angular range $2 \theta$ ranging from 0 to $100^{\circ}$ in continuous mode with a scan speed $5 \mathrm{deg} / \mathrm{min}$. Scanning electron microscope JEOL JSM-6510LV, Japan was used to study microstructure of used samples. The melting endotherms of used alloys were obtained using a SDT Q600 V20.9 Build 20 instrument. 
A digital Vickers micro-hardness tester, (Model-FM-7- Japan), was used to measure Vickers hardness values of used alloys. Internal friction $\mathrm{Q}^{-1}$ and the elastic constants of used alloys were determined using the dynamic resonance method [16-18].

\section{RESULTS AND DISCUSSIONS}

Structure

X-ray diffraction patterns of $\mathrm{Sn}_{80-\mathrm{x}} \mathrm{Sb}_{15} \mathrm{~Pb}_{5}\left(\mathrm{TiO}_{2}\right)_{\mathrm{x}}(\mathrm{x}=0.5,1$ and $1.5 \mathrm{wt} . \%$ ) rapidly solidified alloys have lines corresponding to $\beta$ $\mathrm{Sn}, \mathrm{Pb}, \mathrm{Sb}$ and $\mathrm{SbSn}$ intermetallic phases as shown in Figure 1. X-ray analysis of $\mathrm{Sn}_{80} \mathrm{Sb}_{15} \mathrm{~Pb}_{5}$ show that, formed phases (intensity, peak broadness, miller indices, position (20), and area under peaks) changed after adding of $\left(\mathrm{TiO}_{2}\right)_{\mathrm{x}}$. That is because $\mathrm{TiO}_{2}$ disappeared, dissolved in the matrix of alloy. Also crystal particle size of $\beta-\mathrm{Sn}$ in $\mathrm{Sn}_{80} \mathrm{Sb}_{15} \mathrm{~Pb}_{5}$ alloy increased after adding $\mathrm{TiO}_{2}$ as seen in Table 1 .
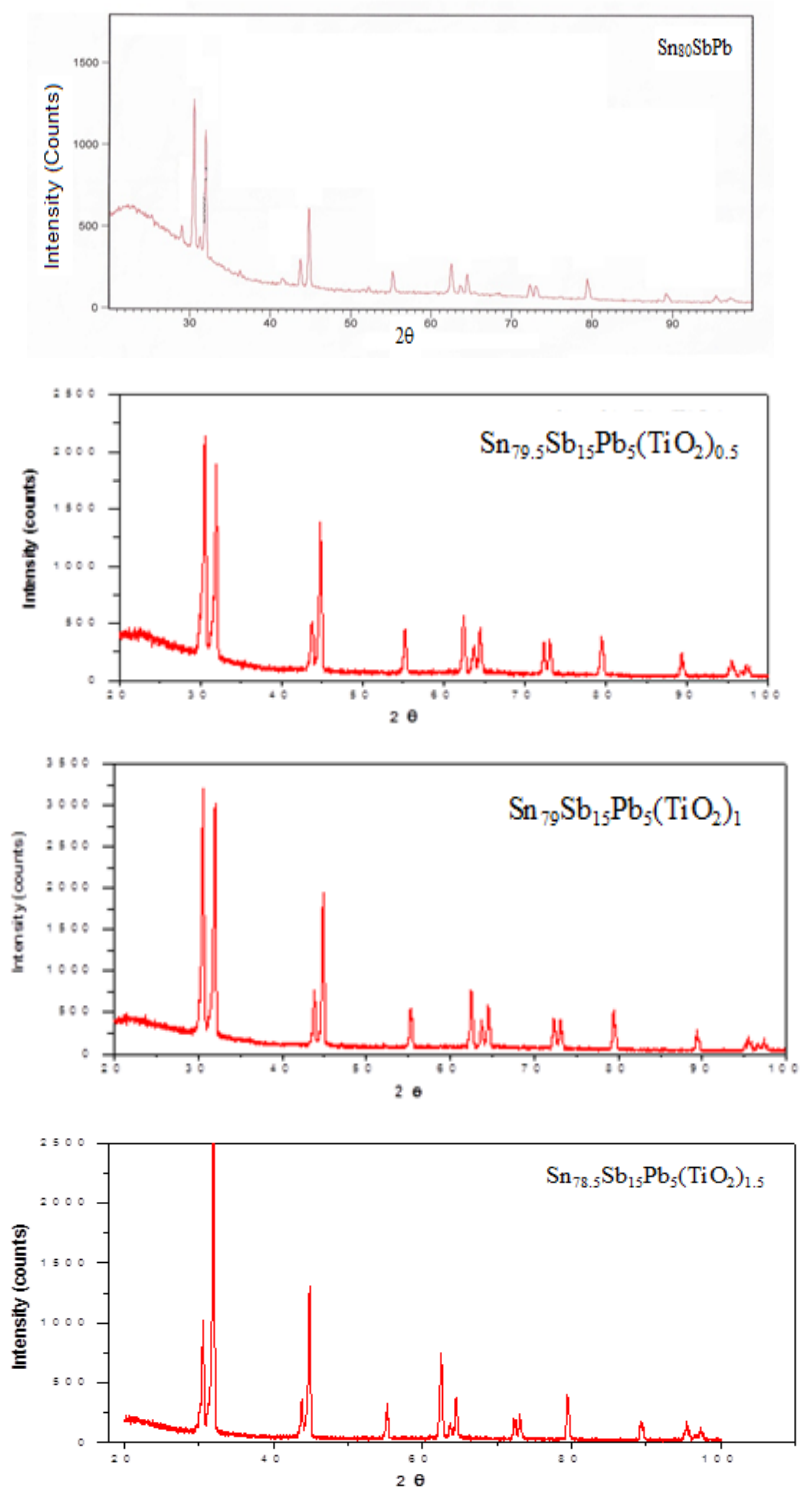

Figure 1:- $\mathrm{x}$-ray diffraction patterns of $\mathrm{Sn}_{80-\mathrm{x}} \mathrm{Sb}_{10} \mathrm{~Pb}_{5}\left(\mathrm{TiO}_{2}\right)_{\mathrm{x}}$ alloys
Table 1:- crystal particle size of $\beta$ - $\mathrm{Sn}$ in $\mathrm{Sn}_{80-\mathrm{x}} \mathrm{Sb}_{10} \mathrm{~Pb}_{5}\left(\mathrm{TiO}_{2}\right)_{\mathrm{x}}$ alloys

\begin{tabular}{|c|c|}
\hline Samples & Particle size $\AA$ \\
\hline $\mathrm{Sn}_{80} \mathrm{Sb}_{15} \mathrm{~Pb}_{5}$ & 317.25 \\
\hline $\mathrm{Sn}_{79.5} \mathrm{Sb}_{15} \mathrm{~Pb}_{5}\left(\mathrm{TiO}_{2}\right)_{0.5}$ & 395.12 \\
\hline $\mathrm{Sn}_{79} \mathrm{Sb}_{15} \mathrm{~Pb}_{5}\left(\mathrm{TiO}_{2}\right)_{1}$ & 448.06 \\
\hline $\mathrm{Sn}_{78.5} \mathrm{Sb}_{15} \mathrm{~Pb}_{5}\left(\mathrm{TiO}_{2}\right)_{1.5}$ & 415.38 \\
\hline
\end{tabular}

Scanning electron micrographs, SEM, of $\mathrm{Sn}_{80}$ ${ }_{x} \mathrm{Sb}_{15} \mathrm{~Pb}_{5}\left(\mathrm{TiO}_{2}\right)_{\mathrm{x}}$ alloys show heterogeneous structure as shown in Figure 2 and that agreed with $\mathrm{x}$-ray analysis. Adding $\mathrm{TiO}_{2}$ caused change in microstructure of $\mathrm{Sn}_{80} \mathrm{Sb}_{15} \mathrm{~Pb}_{5}$ alloy.
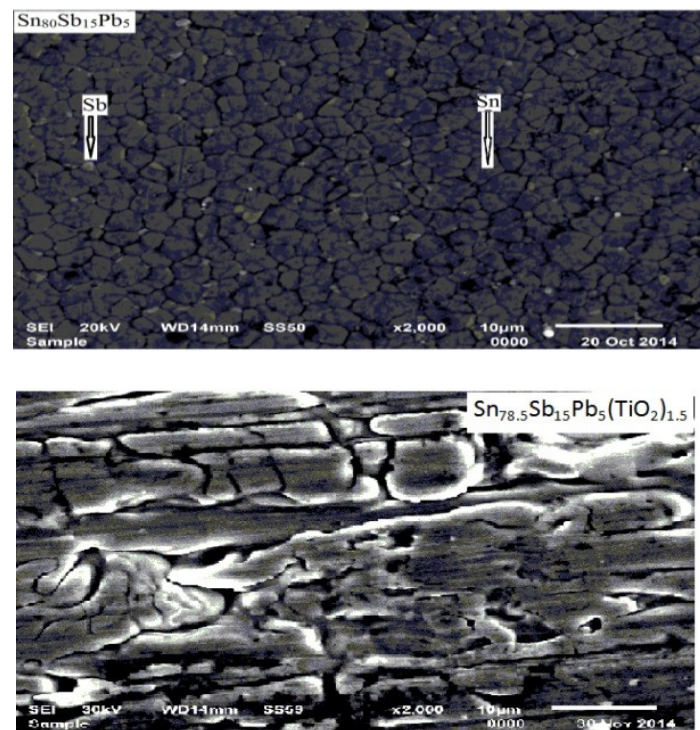

Figure 2:- $\mathrm{SEM}$ of $\mathrm{Sn}_{80-\mathrm{x}} \mathrm{Sb}_{10} \mathrm{~Pb}_{5}\left(\mathrm{TiO}_{2}\right)_{\mathrm{x}}$ alloys

X-ray diffraction patterns of $\mathrm{Sn}_{60-\mathrm{x}} \mathrm{Al}_{20} \mathrm{Sb}_{15} \mathrm{~Pb}_{5}\left(\mathrm{TiO}_{2}\right)_{\mathrm{x}}(\mathrm{x}=$ $0.5,1$ and 1.5 wt.\%) rapidly solidified alloys have lines corresponding to $\beta-\mathrm{Sn}, \mathrm{Pb}, \mathrm{Sb}$ and $\mathrm{SbSn}$ intermetallic phases as shown in Figure 3. $\mathrm{X}$-ray analysis of $\mathrm{Sn}_{60} \mathrm{Al}_{20} \mathrm{Sb}_{15} \mathrm{~Pb}_{5}$ show that, formed phases (intensity,

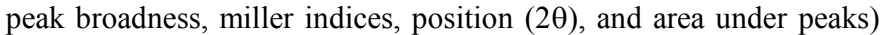
changed after adding of $\left(\mathrm{TiO}_{2}\right)_{\mathrm{x}}$. That is because $\mathrm{Al}$ and $\mathrm{TiO}_{2}$ disappeared $\backslash$ or not detected, dissolved in the matrix of alloy. Also crystal particle size of $\beta$ - $\mathrm{Sn}$ in $\mathrm{Sn}_{60} \mathrm{Al}_{20} \mathrm{Sb}_{15} \mathrm{~Pb}_{5}$ alloy increased after adding $\mathrm{TiO}_{2}$ as seen in Table 2 .

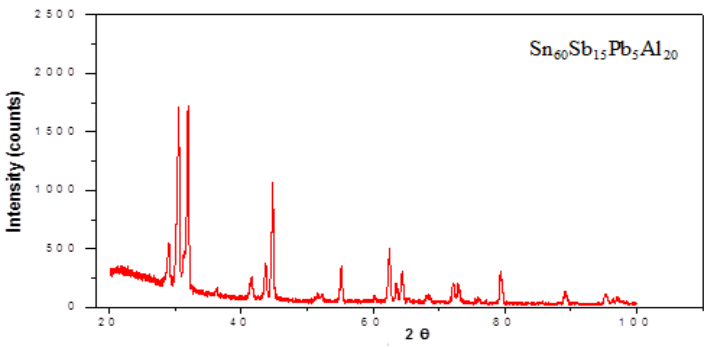



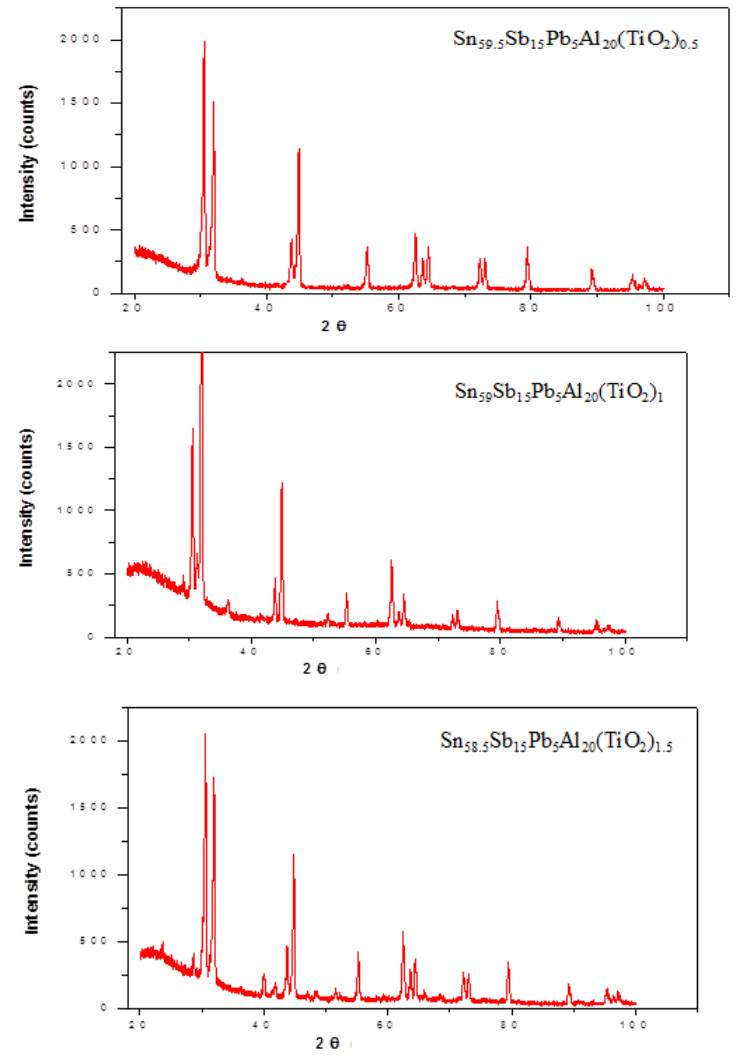

Figure 3:- x-ray diffraction patterns of $\mathrm{Sn}_{60-\mathrm{x}} \mathrm{Al}_{20} \mathrm{Sb}_{15} \mathrm{~Pb}_{5}\left(\mathrm{TiO}_{2}\right)_{\mathrm{x}}$ alloys

Table 2:- crystal particle size of $\beta$ - $\mathrm{Sn}$ in $\mathrm{Sn}_{60-\mathrm{x}} \mathrm{Al}_{20} \mathrm{Sb}_{15} \mathrm{~Pb}_{5}\left(\mathrm{TiO}_{2}\right)_{\mathrm{x}}$ alloys

\begin{tabular}{|c|c|}
\hline Samples & Particle size $\AA$ \\
\hline $\mathrm{Sn}_{60} \mathrm{Al}_{20} \mathrm{Sb}_{15} \mathrm{~Pb}_{5}$ & 337.70 \\
\hline $\mathrm{Sn}_{59.5} \mathrm{Al}_{20} \mathrm{Sb}_{15} \mathrm{~Pb}_{5}\left(\mathrm{TiO}_{2}\right)_{0.5}$ & 412.47 \\
\hline $\mathrm{Sn}_{59} \mathrm{Al}_{20} \mathrm{Sb}_{15} \mathrm{~Pb}_{5}\left(\mathrm{TiO}_{2}\right)_{1}$ & 409.78 \\
\hline $\mathrm{Sn}_{58.5} \mathrm{Al}_{20} \mathrm{Sb}_{15} \mathrm{~Pb}_{5}\left(\mathrm{TiO}_{2}\right)_{1.5}$ & 368.36 \\
\hline
\end{tabular}

Scanning electron micrographs, SEM, of $\mathrm{Sn}_{60-}$ ${ }_{x} \mathrm{Al}_{20} \mathrm{Sb}_{15} \mathrm{~Pb}_{5}\left(\mathrm{TiO}_{2}\right)_{\mathrm{x}}$ alloys show heterogeneous structure as shown in Figure 4 and that agreed with $\mathrm{x}$-ray analysis.

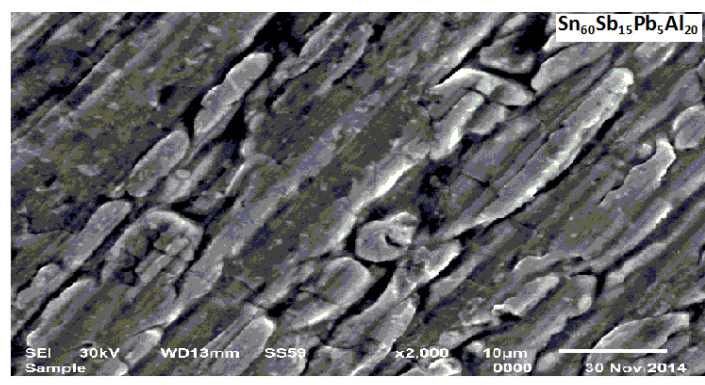

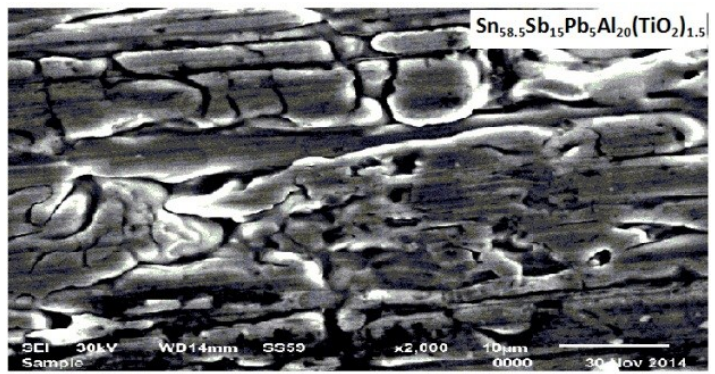

Figure 4:- $\mathrm{SEM}$ of $\mathrm{Sn}_{60-\mathrm{x}} \mathrm{Al}_{20} \mathrm{Sb}_{15} \mathrm{~Pb}_{5}\left(\mathrm{TiO}_{2}\right)_{\mathrm{x}}$ alloys

\section{Mechanical properties}

The elastic constants are directly related to atomic bonding and structure. Elastic modului of $\mathrm{Sn}_{80-\mathrm{x}} \mathrm{Sb}_{10} \mathrm{~Pb}_{5}\left(\mathrm{TiO}_{2}\right)_{\mathrm{x}}$ alloys are listed in Table 3. Elastic modulus of $\mathrm{Sn}_{80} \mathrm{Sb}_{15} \mathrm{~Pb}_{5}$ alloy increased after adding $\mathrm{TiO}_{2}$ nanoparticles.

The resonance curves of $\mathrm{Sn}_{80-\mathrm{x}} \mathrm{Sb}_{10} \mathrm{~Pb}_{5}\left(\mathrm{TiO}_{2}\right)_{\mathrm{x}}$ alloys are shown in Figure 5. Calculated internal friction and thermal diffusivity of $\mathrm{Sn}_{80-\mathrm{x}} \mathrm{Sb}_{10} \mathrm{~Pb}_{5}\left(\mathrm{TiO}_{2}\right)_{\mathrm{x}}$ alloys are listed in Table 3. Internal friction of $\mathrm{Sn}_{87} \mathrm{Sb}_{10} \mathrm{~Pb}_{3}$ alloy varied after adding $\mathrm{TiO}_{2}$ nanoparticles.

The $\mathrm{Sn}_{79} \mathrm{Sb}_{15} \mathrm{~Pb}_{5}\left(\mathrm{TiO}_{2}\right)_{1}$ alloy has better bearing properties such as lowest internal friction, high elastic modulus and higher thermal diffusivity for industrial applications.

Table 3:- elastic modului, internal friction and thermal diffusivity of $\mathrm{Sn}_{80-\mathrm{x}} \mathrm{Sb}_{10} \mathrm{~Pb}_{5}\left(\mathrm{TiO}_{2}\right)_{\mathrm{x}}$ alloys

\begin{tabular}{|c|c|c|c|c|c|}
\hline Samples & $\begin{array}{c}\mathrm{E} \\
\mathrm{GPa}\end{array}$ & $\begin{array}{c}\mu \\
\mathrm{GPa}\end{array}$ & $\begin{array}{c}\mathrm{B} \\
\mathrm{GPa}\end{array}$ & $\mathrm{Q}^{-1}$ & $\begin{array}{c}\mathrm{D}_{\text {th }} \times 10^{-8} \\
\mathrm{~m}^{2} \backslash \mathrm{sec}\end{array}$ \\
\hline $\mathrm{Sn}_{80} \mathrm{Sb}_{15} \mathrm{~Pb}_{5}$ & 24.28 & 8.93 & 28.80 & 0.034 & 21.12 \\
\hline $\mathrm{Sn}_{79.5} \mathrm{Sb}_{15} \mathrm{~Pb}_{5}\left(\mathrm{TiO}_{2}\right)_{0.5}$ & 32.96 & 12.18 & 37.49 & 0.036 & 17.7 \\
\hline $\mathrm{Sn}_{79} \mathrm{Sb}_{15} \mathrm{~Pb}_{5}\left(\mathrm{TiO}_{2}\right)_{1}$ & 38.25 & 14.08 & 45.09 & 0.029 & 34.5 \\
\hline $\mathrm{Sn}_{78.5} \mathrm{Sb}_{15} \mathrm{~Pb}_{5}\left(\mathrm{TiO}_{2}\right)_{1.5}$ & 42.67 & 15.71 & 50.12 & 0.041 & 12.3 \\
\hline
\end{tabular}

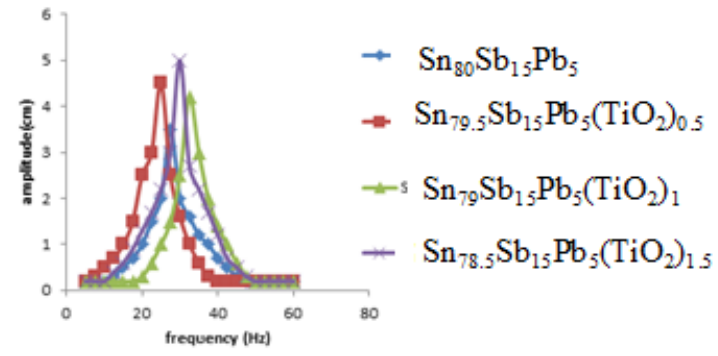

Figure 5:- resonance curves of $\mathrm{Sn}_{80}-\mathrm{x} \mathrm{Sb}_{10} \mathrm{~Pb}_{5}\left(\mathrm{TiO}_{2}\right)_{\mathrm{x}}$ alloys

Elastic modului of $\mathrm{Sn}_{60-\mathrm{x}} \mathrm{Al}_{20} \mathrm{Sb}_{15} \mathrm{~Pb}_{5}\left(\mathrm{TiO}_{2}\right)_{\mathrm{x}}$ alloys are listed in Table 4. Elastic modulus of $\mathrm{Sn}_{60} \mathrm{Al}_{20} \mathrm{Sb}_{15} \mathrm{~Pb}_{5}$ alloy varied after adding $\mathrm{TiO}_{2}$ nanoparticles.

The resonance curves of $\mathrm{Sn}_{60-\mathrm{x}} \mathrm{Al}_{20} \mathrm{Sb}_{15} \mathrm{~Pb}_{5}\left(\mathrm{TiO}_{2}\right)_{\mathrm{x}}$ alloys are shown in Figure 6. Calculated internal friction and thermal diffusivity of $\mathrm{Sn}_{60-\mathrm{x}} \mathrm{Al}_{20} \mathrm{Sb}_{15} \mathrm{~Pb}_{5}\left(\mathrm{TiO}_{2}\right)_{\mathrm{x}}$ alloys are listed in Table 4. Internal friction of $\mathrm{Sn}_{60} \quad \mathrm{Al}_{20} \mathrm{Sb}_{15} \mathrm{~Pb}_{5}$ alloy varied after adding $\mathrm{TiO}_{2}$ nanoparticles. 
The $\mathrm{Sn}_{59} \mathrm{Al}_{20} \mathrm{Sb}_{15} \mathrm{~Pb}_{5}\left(\mathrm{TiO}_{2}\right)_{1}$ alloy has better bearing properties such as adequate internal friction, high elastic modulus and higher thermal diffusivity for industrial applications.

Table 4:- elastic modului, internal friction and thermal diffusivity of $\mathrm{Sn}_{60-\mathrm{x}} \mathrm{Al}_{20} \mathrm{Sb}_{15} \mathrm{~Pb}_{5}\left(\mathrm{TiO}_{2}\right)_{\mathrm{x}}$ alloys

\begin{tabular}{|c|c|c|c|c|c|}
\hline Samples & $\begin{array}{c}\mathrm{E} \\
\mathrm{GPa}\end{array}$ & $\begin{array}{c}\mu \\
\mathrm{GPa}\end{array}$ & $\begin{array}{c}\mathrm{B} \\
\mathrm{GPa}\end{array}$ & $\mathrm{Q}^{-1}$ & $\begin{array}{c}\mathrm{D}_{\text {th }} \mathrm{x} 10^{-8} \\
\mathrm{~m}^{2} \backslash \text { sec }\end{array}$ \\
\hline $\mathrm{Sn}_{60} \mathrm{Al}_{20} \mathrm{Sb}_{15} \mathrm{~Pb}_{5}$ & 38.95 & 14.35 & 45.56 & 0.031 & 12.1 \\
\hline $\mathrm{Sn}_{59.5 \mathrm{Al}_{20} \mathrm{Sb}_{15} \mathrm{~Pb}_{5}\left(\mathrm{TiO}_{2}\right)_{0.5}}$ & 36.99 & 13.63 & 43.11 & 0.033 & 16 \\
\hline $\mathrm{Sn}_{59} \mathrm{Al}_{20} \mathrm{Sb}_{15} \mathrm{~Pb}_{5}\left(\mathrm{TiO}_{2}\right)_{1}$ & 42.22 & 15.56 & 49.07 & 0.036 & 18.5 \\
\hline $\mathrm{Sn}_{58.5} \mathrm{Al}_{20} \mathrm{Sb}_{15} \mathrm{~Pb}_{5}\left(\mathrm{TiO}_{2}\right)_{1.5}$ & 37.55 & 13.85 & 43.49 & 0.030 & 13.6 \\
\hline
\end{tabular}

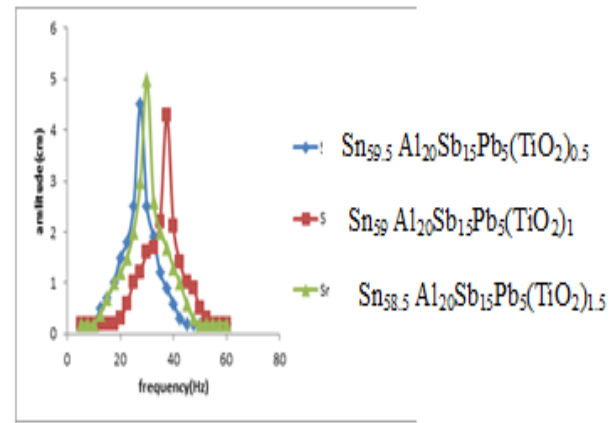

Figure 6:- resonance curves of $\mathrm{Sn}_{60-\mathrm{x}} \mathrm{Al}_{20} \mathrm{Sb}_{15} \mathrm{~Pb}_{5}\left(\mathrm{TiO}_{2}\right)_{\mathrm{x}}$ alloys

\section{Thermal properties}

Thermal analysis is often used to study solid state transformations as well as solid-liquid reactions. Figure 7 shows DSC thermographs for $\mathrm{Sn}_{80-\mathrm{x}} \mathrm{Sb}_{10} \mathrm{~Pb}_{5}\left(\mathrm{TiO}_{2}\right)_{\mathrm{x}}$ alloys. Variation occurred in exothermal peak of $\mathrm{Sn}_{80} \mathrm{Sb}_{10} \mathrm{~Pb}_{5}$ alloy. The melting temperature and other thermal properties of $\mathrm{Sn}_{80-\mathrm{x}} \mathrm{Sb}_{10} \mathrm{~Pb}_{5}\left(\mathrm{TiO}_{2}\right)_{\mathrm{x}}$ alloys are listed in Table 5. Melting temperature of $\mathrm{Sn}_{80} \mathrm{Sb}_{10} \mathrm{~Pb}_{5}$ alloy decreased after adding $\mathrm{TiO}_{2}$ nanoparticles.

Specific heat, enthalpy and thermal conductivity of $\mathrm{Sn}_{80} \mathrm{Sb}_{10} \mathrm{~Pb}_{5}$ alloy varied after adding $\mathrm{TiO}_{2}$ nanoparticles. That is because $\mathrm{TiO}_{2}$ nanoparticles due change in matrix microstructure of $\mathrm{Sn}_{80} \mathrm{Sb}_{10} \mathrm{~Pb}_{5}$ alloy.

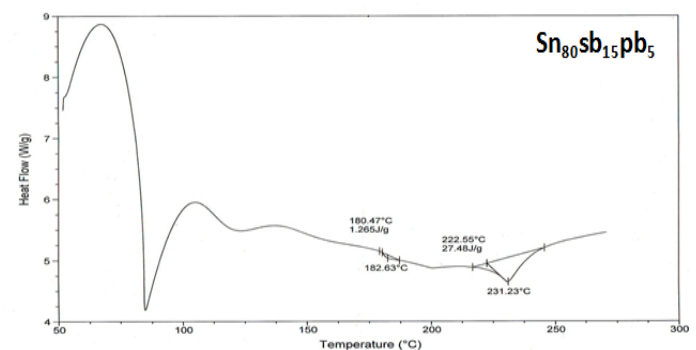

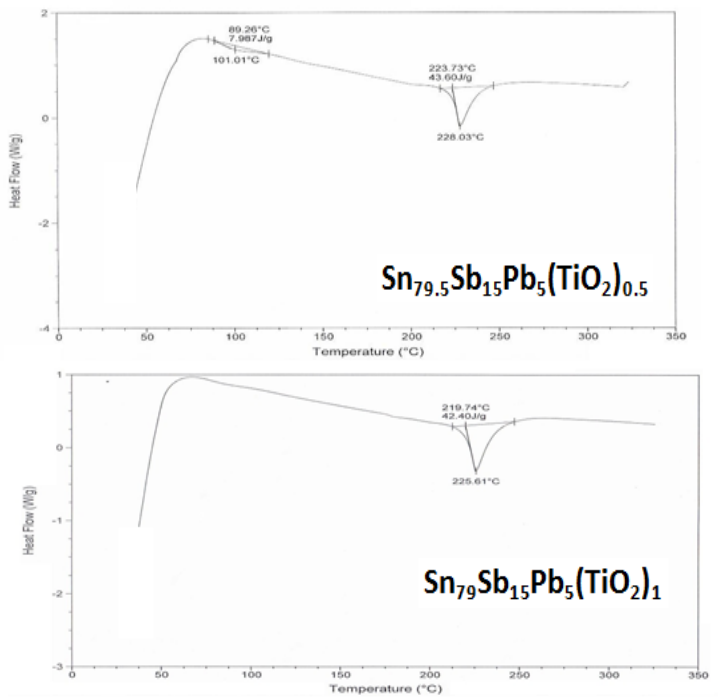

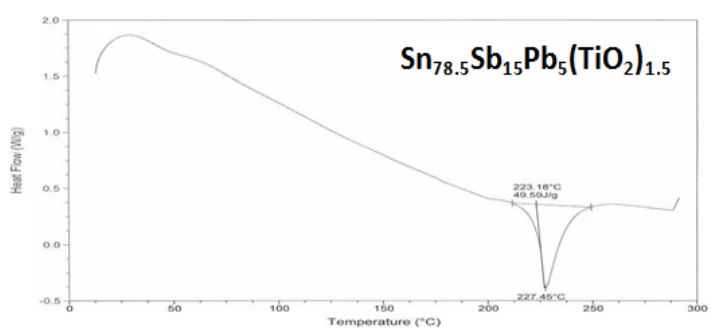

Figure 7:- DSC of $\mathrm{Sn}_{87-x} \mathrm{Sb}_{10} \mathrm{~Pb}_{3}\left(\mathrm{TiO}_{2}\right)_{\mathrm{x}}$ alloys

Table 5:- melting point and other thermal properties of $\mathrm{Sn}_{80-\mathrm{x}} \mathrm{Sb}_{10} \mathrm{~Pb}_{5}\left(\mathrm{TiO}_{2}\right)_{\mathrm{x}}$ alloys

\begin{tabular}{|c|c|c|c|c|}
\hline Samples & $\begin{array}{c}\text { Melting } \\
\text { point }{ }^{\circ} \mathrm{C}\end{array}$ & $\begin{array}{c}\mathrm{C}_{\mathrm{P}} \\
\mathrm{J} / \mathrm{g} .{ }^{\circ} \mathrm{C}\end{array}$ & $\begin{array}{c}\Delta \mathrm{S} \\
\text { J/g. }{ }^{\circ} \mathrm{C}\end{array}$ & $\begin{array}{c}\mathrm{K} \\
\mathrm{W} . \mathrm{m}^{-1} . \mathrm{K}^{-1}\end{array}$ \\
\hline $\mathrm{Sn}_{80} \mathrm{Sb}_{15} \mathrm{~Pb}_{5}$ & 231.23 & 0.12 & 1.57 & 1.65 \\
\hline $\mathrm{Sn}_{79.5} \mathrm{Sb}_{15} \mathrm{~Pb}_{5}\left(\mathrm{TiO}_{2}\right)_{0.5}$ & 228.03 & 3.41 & 0.189 & 1.86 \\
\hline $\mathrm{Sn}_{79} \mathrm{Sb}_{15} \mathrm{~Pb}_{5}\left(\mathrm{TiO}_{2}\right)_{1}$ & 225.61 & 2.53 & 0.185 & 1.46 \\
\hline $\mathrm{Sn}_{78.5} \mathrm{Sb}_{15} \mathrm{~Pb}_{5}\left(\mathrm{TiO}_{2}\right)_{1.5}$ & 227.45 & 3.35 & 0.215 & 2.77 \\
\hline
\end{tabular}

Figure 8 shows DSC thermographs for $\mathrm{Sn}_{60}$ ${ }_{x} \mathrm{Al}_{20} \mathrm{Sb}_{15} \mathrm{~Pb}_{5}\left(\mathrm{TiO}_{2}\right)_{\mathrm{x}}$ alloys. Variation occurred in exothermal peak of $\mathrm{Sn}_{60} \mathrm{Al}_{20} \mathrm{Sb}_{15} \mathrm{~Pb}_{5}$ alloy. The melting temperature and other thermal properties of $\mathrm{Sn}_{60-\mathrm{x}} \mathrm{Al}_{20} \mathrm{Sb}_{15} \mathrm{~Pb}_{5}\left(\mathrm{TiO}_{2}\right)_{\mathrm{x}}$ alloys are listed in Table 7. Melting temperature of $\mathrm{Sn}_{60} \mathrm{Al}_{20} \mathrm{Sb}_{15} \mathrm{~Pb}_{5}$ alloy varied after adding $\mathrm{TiO}_{2}$ nanoparticles.

Specific heat, enthalpy and thermal conductivity of $\mathrm{Sn}_{80} \mathrm{Sb}_{10} \mathrm{~Pb}_{5}$ alloy varied after adding $\mathrm{TiO}_{2}$ nanoparticles. That is because $\mathrm{TiO}_{2}$ nanoparticles due change in matrix microstructure of $\mathrm{Sn}_{60} \mathrm{Al}_{20} \mathrm{Sb}_{15} \mathrm{~Pb}_{5}$ alloy. 

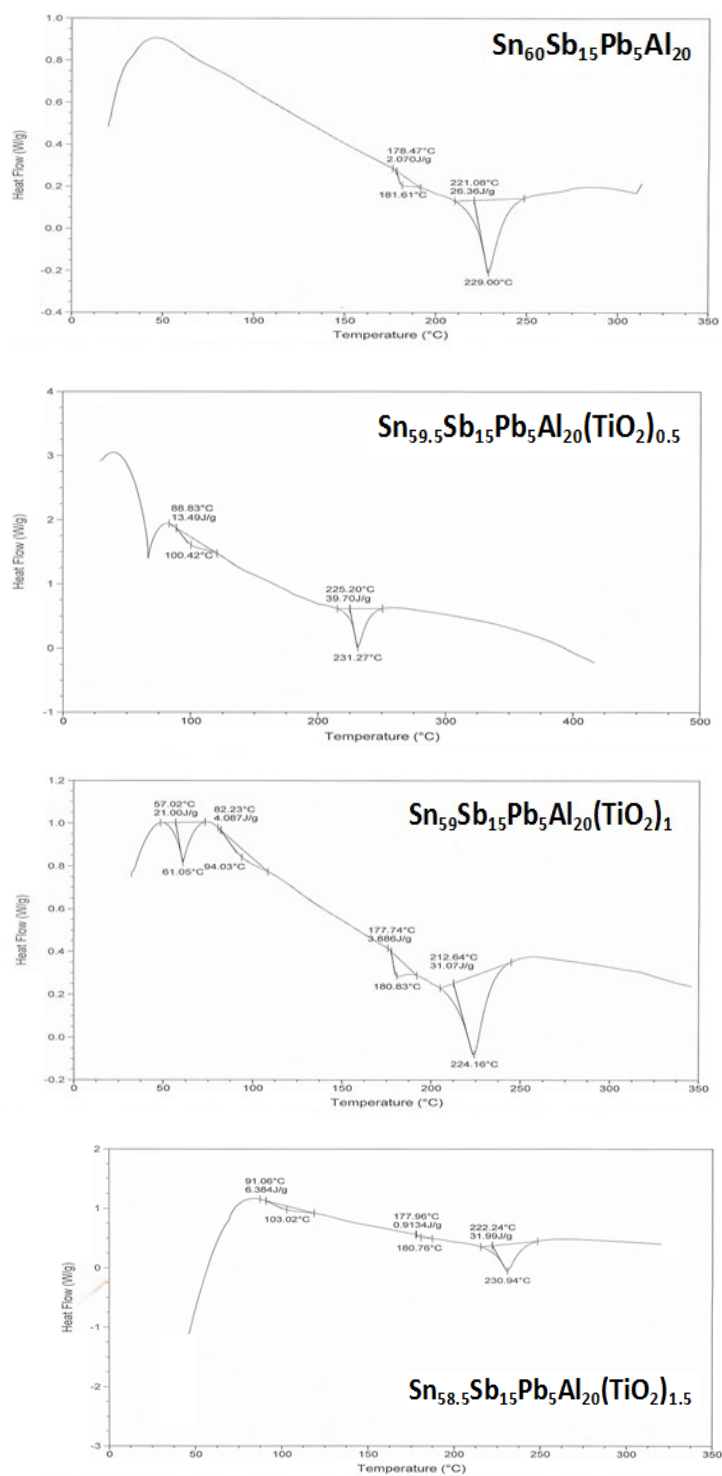

Figure 8:- $\mathrm{DSC}$ of $\mathrm{Sn}_{60-\mathrm{x}} \mathrm{Al}_{20} \mathrm{Sb}_{15} \mathrm{~Pb}_{5}\left(\mathrm{TiO}_{2}\right)_{\mathrm{x}}$ alloys

Table 6:- melting point and other thermal properties of $\mathrm{Sn}_{60-\mathrm{x}} \mathrm{Al}_{20} \mathrm{Sb}_{15} \mathrm{~Pb}_{5}\left(\mathrm{TiO}_{2}\right)_{\mathrm{x}}$ alloys

\begin{tabular}{|c|c|c|c|c|}
\hline Samples & $\begin{array}{l}\text { Melting } \\
\text { point }{ }^{\circ} \mathrm{C}\end{array}$ & $\begin{array}{c}\mathrm{C}_{\mathrm{P}} \\
\mathrm{J} / \mathrm{g} \cdot{ }^{\circ} \mathrm{C}\end{array}$ & $\begin{array}{c}\Delta \mathrm{S} \\
\mathrm{J} / \mathrm{g} \cdot{ }^{\circ} \mathrm{C}\end{array}$ & $\begin{array}{c}\mathrm{K} \\
\mathrm{W} \cdot \mathrm{m}^{-1} \cdot \mathrm{K}^{-1}\end{array}$ \\
\hline $\mathrm{Sn}_{60} \mathrm{Al}_{20} \mathrm{Sb}_{15} \mathrm{~Pb}_{5}$ & 229 & 1.6 & 0.11 & 2.08 \\
\hline $\mathrm{Sn}_{59.5} \mathrm{Al}_{20} \mathrm{Sb}_{15} \mathrm{~Pb}_{5}\left(\mathrm{TiO}_{2}\right)_{0.5}$ & 231.27 & 2.46 & 0.18 & 2.28 \\
\hline $\mathrm{Sn}_{59} \mathrm{Al}_{20} \mathrm{Sb}_{15} \mathrm{~Pb}_{5}\left(\mathrm{TiO}_{2}\right)_{1}$ & 224.16 & 1.48 & 0.14 & 2.03 \\
\hline $\mathrm{Sn}_{58.5} \mathrm{Al}_{20} \mathrm{Sb}_{15} \mathrm{~Pb}_{5}\left(\mathrm{TiO}_{2}\right)_{1.5}$ & 230.94 & 1.97 & 0.14 & 1.62 \\
\hline
\end{tabular}

\section{Creep behavior}

Creep behavior of $\mathrm{Sn}_{80-} \mathrm{Sb}_{10} \mathrm{~Pb}_{5}\left(\mathrm{TiO}_{2}\right)_{x}$ and $\mathrm{Sn}_{60}$ ${ }_{x} \mathrm{Al}_{20} \mathrm{Sb}_{15} \mathrm{~Pb}_{5}\left(\mathrm{TiO}_{2}\right)_{\mathrm{x}}$ alloys were investigated by indentation method
(Vickers hardness test) performed at room temperature. The indentation creep data are shown in Figure 9, where the indentation length is plotted against the indentation time applying constant load of $10 \mathrm{~g}$. The indentation length increases with the indentation time. In the Mulheam-Tabor method, Figure 9, Vickers hardness number of $\mathrm{Sn}_{80-\mathrm{x}} \mathrm{Sb}_{10} \mathrm{~Pb}_{5}\left(\mathrm{TiO}_{2}\right)_{\mathrm{x}}$ and $\mathrm{Sn}_{60-\mathrm{x}} \mathrm{Al}_{20} \mathrm{Sb}_{15} \mathrm{~Pb}_{5}\left(\mathrm{TiO}_{2}\right)_{\mathrm{x}}$ alloys are plotted versus indentation time on log-log scale for the indentation data. It is observed that there exists a linear relationship between indentation time and hardness for all conditions. The slope of the resultant lines according Mulheam-Tabor method is $-\left(n+\frac{1}{2}\right)$ where $\mathrm{n}$ is the stress exponent. The stress exponent values of $\mathrm{Sn}_{80-\mathrm{x}} \mathrm{Sb}_{10} \mathrm{~Pb}_{5}\left(\mathrm{TiO}_{2}\right)_{\mathrm{x}}$ and $\mathrm{Sn}_{60}-\mathrm{A} \mathrm{Al}_{20} \mathrm{Sb}_{15} \mathrm{~Pb}_{5}\left(\mathrm{TiO}_{2}\right)_{x}$ alloys are given in Table 7 . These exponent values are in the range of 2.16 to 5.75 depending on the composition of used alloy and that agreed with the pervious results $(\mathrm{n}=$ 4.5 [19] and $n \sim 5.3$ to 5.6 and 5.8 to 5.9 [20]. The change in stress exponent values are attributable to microstructural features (changing in $\beta$ matrix such as change in the lattice parameters, solid solution, size and distribution of strengthening phases, intermetallic phases) and that is agree with the pervious results [21].
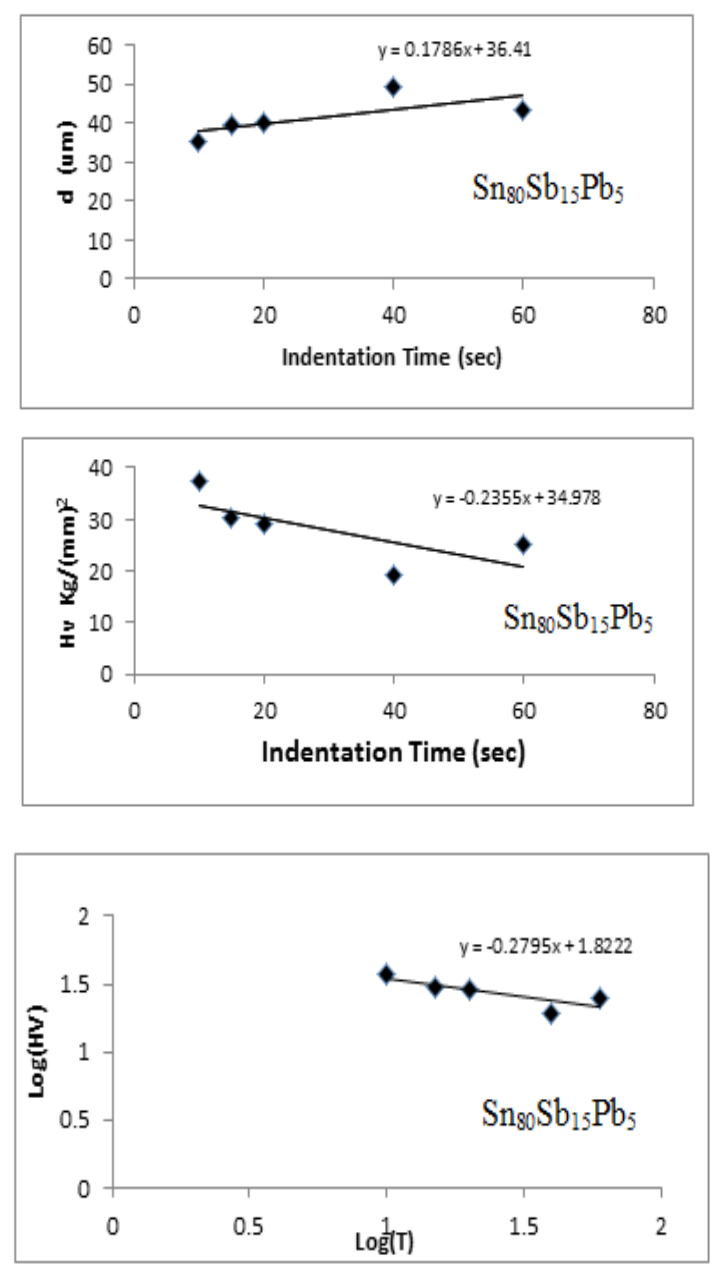

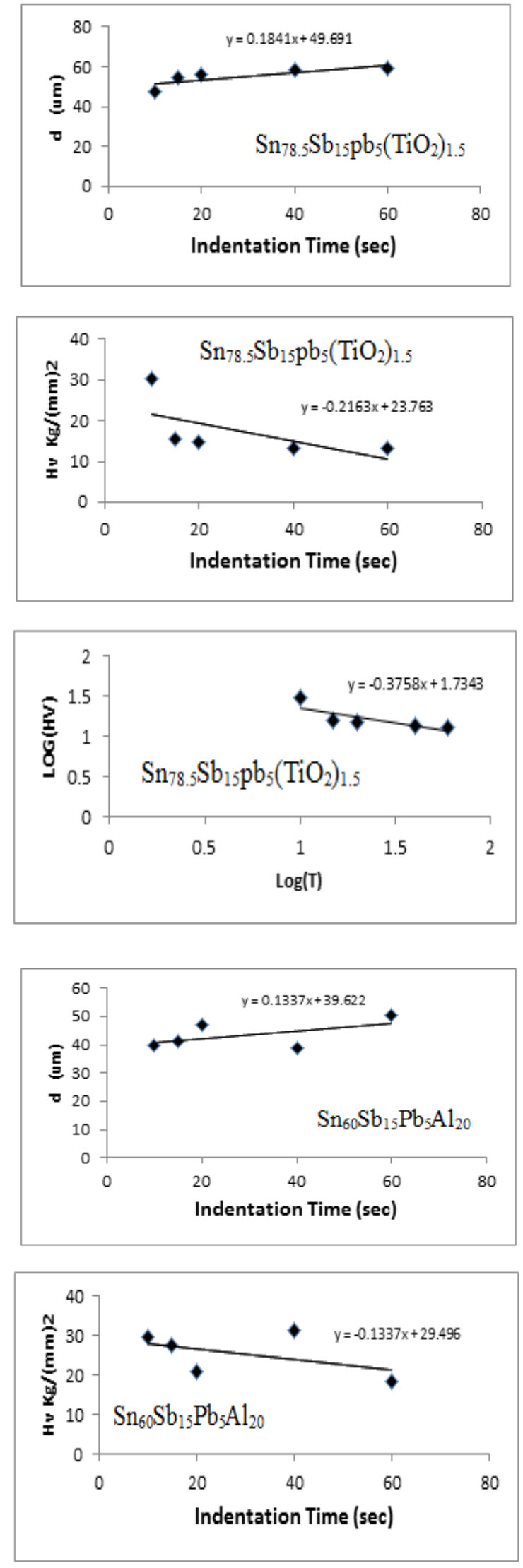
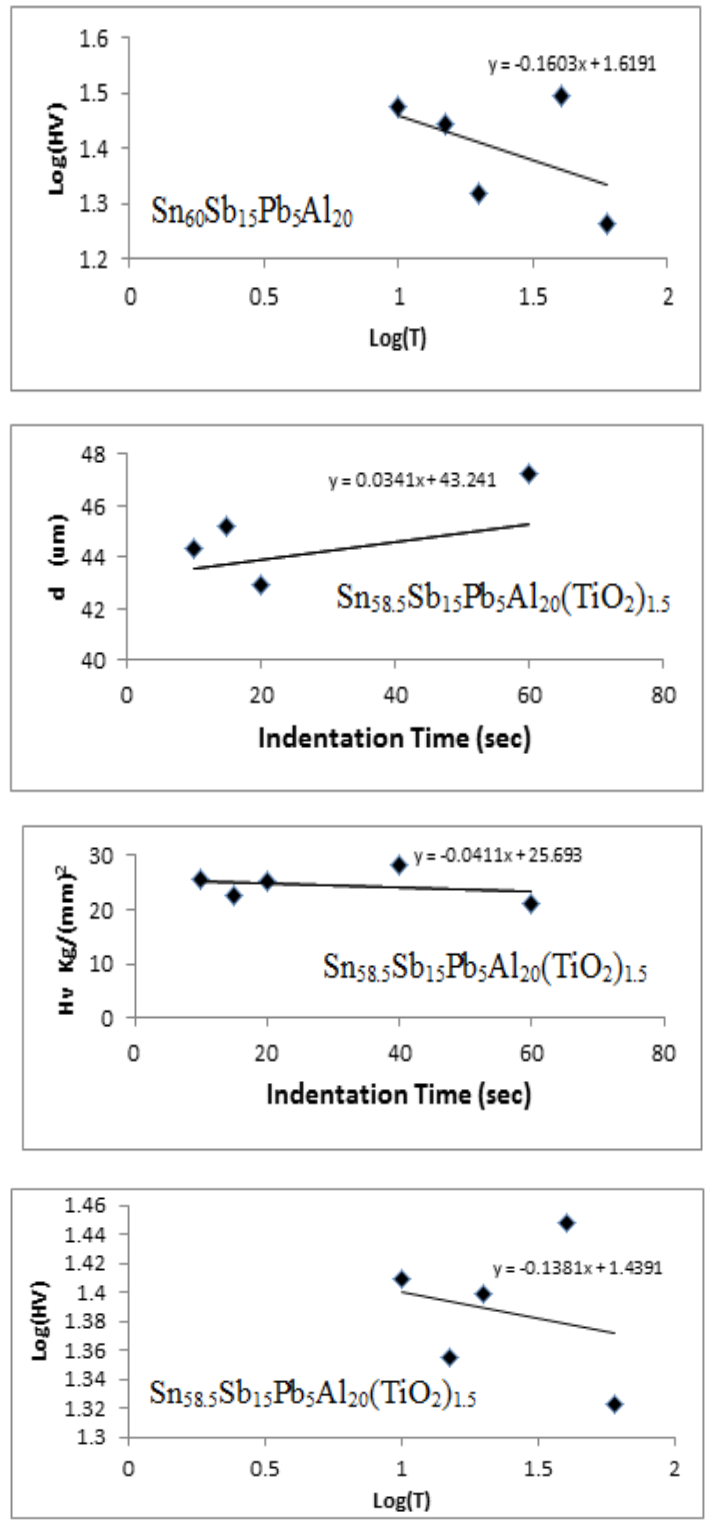

Figure 9:- indentation creep data of $\mathrm{Sn}_{80-\mathrm{x}} \mathrm{Sb}_{10} \mathrm{~Pb}_{5}\left(\mathrm{TiO}_{2}\right)_{\mathrm{x}}$ and $\mathrm{Sn}_{60-\mathrm{x}} \mathrm{Al}_{20} \mathrm{Sb}_{15} \mathrm{~Pb}_{5}\left(\mathrm{TiO}_{2}\right)_{\mathrm{x}}$ alloys

Table 7:- stress exponent of and $\mathrm{Sn}_{80-\mathrm{x}} \mathrm{Sb}_{10} \mathrm{~Pb}_{5}\left(\mathrm{TiO}_{2}\right)_{\mathrm{x}}$ $\mathrm{Sn}_{60-\mathrm{x}} \mathrm{Al}_{20} \mathrm{Sb}_{15} \mathrm{~Pb}_{5}\left(\mathrm{TiO}_{2}\right)_{\mathrm{x}}$ alloys

\begin{tabular}{|c|c|}
\hline Samples & Stress exponent (n) \\
\hline $\mathrm{Sn}_{80} \mathrm{Sb}_{15} \mathrm{~Pb}_{5}$ & 3.077 \\
\hline $\mathrm{Sn}_{78.5} \mathrm{Sb}_{15} \mathrm{~Pb}_{5}\left(\mathrm{TiO}_{2}\right)_{1.5}$ & 2.16 \\
\hline & \\
\hline $\mathrm{Sn}_{60} \mathrm{Al}_{20} \mathrm{Sb}_{15} \mathrm{~Pb}_{5}$ & 5.749 \\
\hline $\mathrm{Sn}_{58.5} \mathrm{Al}_{20} \mathrm{Sb}_{15} \mathrm{~Pb}_{5}\left(\mathrm{TiO}_{2}\right)_{1.5}$ & 2.44 \\
\hline
\end{tabular}

\section{CONCLUSIONS}


Microstructure of tin- antimony- lead and tin- aluminumantimony- lead alloys changed after adding titanium oxide. Stress exponent of tin- antimony- lead and tin- aluminum- antimony- lead alloys decreased after adding titanium oxide. Strengths of tinantimony- lead and tin- aluminum- antimony- lead alloys increased after adding titanium oxide. Internal fiction and thermal parameters of tin- antimony- lead and tin- aluminum- antimony- lead alloys varied after adding titanium oxide. The $\mathrm{Sn}_{79} \mathrm{Sb}_{15} \mathrm{~Pb}_{5}\left(\mathrm{TiO}_{2}\right)_{1}$ and $\mathrm{Sn}_{59}$ $\mathrm{Al}_{20} \mathrm{Sb}_{15} \mathrm{~Pb}_{5}\left(\mathrm{TiO}_{2}\right)_{1}$ alloys have better bearing properties for industrial applications

\section{REFERENCES}

[1] Zeren A, Feyzullahoglu E, Zeren M, Mater. and Design 28 (2007) 318

[2] El-Bediwi A, Radiation Effects \& Defects in Solids 159 (2004) 125

[3] El- Bediwi A, Cryst. Res. Technol 40: 7 (2005) 688

[4] El-Bediwi A, Radiation Effects \& Defects in Solids 159 (2004) 539

[5] Mahmudi R, J. Mater. Sci. 40 (2005) 3361

[6] Mahmudi R and Rezaee-Bazzaz A, Mater. Lett. 59: 13 (2005) 1705

[7] Mahmudi R, Geranmay A.R, Bakher M, Allam M, Mater. Sci. and Eng. A 457 (2007) 173

[8] Esfandyarpour M.J, Mahmudi R, Mater. Sci. and Eng. A 530 (2011) 402

[9] El-Bediwi A, Lashin A.R, Mossa M, Kamal M, Mater. Sci. and Eng. A 528 (2011) 3568

[10] Goudarzi M.M, Jahromi S.A.J, Nazarboland A, Mater. and Design 30 (2009) 2283

[11] Kamal M, Abdel-Salam A, Pieri J.C, J. Mater. Sci 19 (1984) 3880

[12] El- Bediwi A.B, El Said Gouda, Kamal M, AMSE, 65, $\mathrm{n}^{\circ} 1$, Modeling C- 2004

[13] El-Daly A.A, Mohamad A.Z, Fawzy A, El-Taher A.M, Mater. Sci. and Eng. A 528 (2011) 1055

[14] Bora M.O, Coban O, Sinmazcelik T, Gunay V, Zeren M, Mater. and Design 31 (2010) 2707

[15] Xiaowu H, Shuangming L, Lin L, Hengzhi F, The Chinese Journal of Nonferrous Metals 14:1 (2004) 93

[16] Schreiber E, Anderson O. L and Soga N, Elastic constant and their measurements, McGraw-Hill, New York, (1973) 82

[17] Timoshenko S and Goddier J.N, "Theory of elasticity, $2^{\text {nd }}$ Ed", McGraw-Hill, New York, (1951) 277

[18] Nuttall K, J. Inst. Met. 99 (1971) 266

[19] Geranmayeh A. R, Mahmudi R, J Matter Sci. 40 (2005) 3361

[20] Kangooie M, Mahmudi R and Geranmayeh A. R., J Electr. Matter. 39 (2010) 215

[21] Deraki Rani S, Murthy G. S, Mate. Sci. Techn., 403 (2004) 20 
International Journal of Science and Engineering Applications Volume 4 Issue 2, 2015, ISSN-2319-7560 (Online) 
International Journal of Science and Engineering Applications Volume 4 Issue 2, 2015, ISSN-2319-7560 (Online) 